\title{
EFEKTIVITAS WAKTU TERAPI MUSIK LANGGAM JAWA TERHADAP TEKANAN DARAH PADA LANSIA HIPERTENSI DI DESA MUARA RENGAS
}

\author{
Aridayanti Fajar Putri ${ }^{1,}$ Muflih $^{1}$, Santi Damayanti ${ }^{1}$ \\ ${ }^{1}$ Program Studi Keperawatan Program Sarjana, Universitas Respati Yogyakarta \\ Email : aridyntifp@gmail.com
}

\begin{abstract}
Abstrak
Saat mendengarkan musik tubuh merespon dengan terjadinya pelepasan dopamin dari tubuh. Pelepasan dopamin menyebabkan vasodilatasi pembuluh darah sehingga akan berpengaruh pada tekanan darah seseorang. Standar lama waktu untuk terapi musik langgam jawa pada penelitian penelitian sebelumnya ditemukan berbeda - beda. Oleh karena itu perlu dilakukan penelitian untuk membandingkan efektifitasnya. Tujuan dari penelitian untuk mengetahui efektivitas waktu pemberian terapi musik langgam jawa terhadap tekanan darah pada lansia hipertensi di Desa Muara Rengas. Penelitian ini menggunakan metode quasi experiment dengan desain pre and post without control untuk pemilihan responden menggunakan non probability sampling dengan metode consecutive sampling. Hasil uji Wilcoxon, T-Test Paired, Mann Whitney dan T-Test Independent Terdapat pengaruh terapi musik langgam jawa terhadap tekanan darah pada lansia hipertensi pada kelompok 15 menit $\mathrm{p}$ value sistol $0,000(<0,05)$ dan $\mathrm{p}$ value diastol 0,013 dan 30 menit dengan $\mathrm{p}$ value $0,008(<0,05)$ dan $\mathrm{p}$ value diastol $0,029(<0,05)$. Tidak ada perbedaan efektivitas tekanan darah setelah diberikan intervensi musik langgam jawa selama 15 menit dan 30 menit p value sistol 0,320 $(>0,05)$ dan $\mathrm{p}$ value diastol 0,576 $(>0,05)$. Berdasarkan hasil penelitian ini tidak ada perbedaan efektivitas tekanan darah setelah diberikan intervensi musik langgam jawa selama 15 menit dan 30 menit pada lansia hipertensi
\end{abstract}

Kata Kunci : Terapi Musik, Hipertensi, Lansia

\begin{abstract}
When listening to music, the body responds releasing dopamine from the body. The release of dopamine causes vasodilation of blood vessels so that it will affect a person's blood pressure. The standard length of time for Javanese langgam music therapy in previous studies was found to be different. Therefore, it is necessary to do research to compare its effectiveness. The purpose of this research to determine the effectiveness of Javanese langgam music therapy time on blood pressure in elderly persons with hypertension in Muara Rengas village. This research uses a quasiexperimental method with pre and post control design, the selection of respondents uses a nonprobability sampling with a consecutive sampling method. The Wilcoxon test, Paired T-Test, Mann Whitney and Independent T-Test show there is an effect of Javanese langgam music therapy on blood pressure in elderly persons with hypertension in the 15-minute group with a systolic $\mathrm{p}$ value of $0.000(<0.05)$ and a diastolic $p$ value of 0.013 ; and in the 30 -minute group with a $p$ value of 0.008 $(<0.05)$ and a diastolic $\mathrm{p}$ value of $0.029(<0.05)$. There is no effectiveness difference on blood pressure after being given Javanese music intervention for 15 minutes and 30 minutes with a systolic $p$ value of $0.320(>0.05)$ and a diastolic $p$ value of $0.576(>0.05)$. Based on research results there is no effectiveness difference between 15-minute and 30-minute Javanese langgam music intervention in elderly persons with hypertension.
\end{abstract}

Keywords: music therapy, hypertension, elderly persons 


\section{PENDAHULUAN}

Sekitar 970 juta orang di Dunia memiliki tekanan darah tinggi diperkirakan 20251,56 miliar orang akan menderita tekanan darah tinggi dan lansia sangat umum mengalami tekanan darah tinggi(Bell, Twiggs, \& Olin, 2015). Berdasarkan proyeksi data penduduk, diprediksi jumlah penduduk lansia di Indonesia tahun 2020 (27,08 juta), tahun 2025 (33,69 juta), tahun 2030 (40,95 juta) dan tahun 2035 (48,19 juta). Suatu negara dikatakan berstruktur tua jika mempunyai populasi lansia di atas tujuh persen, di Indonesia terdapat 19 provinsi dengan struktur tua salah satunya provinsi sumatera selatan $(7,47 \%)($ Kementerian Kesehatan Republik Indonesia, 2017).

Bertambahnya usia pada lansia menyebabkan terjadinya penurunan fungsi reseptor dan kelenturan pembuluh darah yang berdampak pada tekanan darahnya(LeMone, M.Burke, \& Bauldoff, 2018). Tekanan darah tinggi yang terjadi terus menerus pada pembuluh darah dapat merusak pembuluh darah pada organ yang dituju sehingga menyebabkan penyakit jantung, stroke, serta gagal ginjal apabila tidak ditangani(Smeltzer \& Bare, 2017). Menurut WHO, hipertensi sebagai salah satu penyebab paling paling penting kematian dini di seluruh Dunia diperkirakan menyebabkan 7,5 juta kematian, sekitar 12,8\% dari total kematian(Bell et al., 2015).

Salah satu indikator keberhasilan pembangunan kesehatan di Indonesia adalah meningkatnya umur harapan hidup (UHH) dan menurunnya angka kematian manusia Indonesia. Dengan jumlah lansia yang semakin besar, dapat membawa dampak dibidang kesehatan, ekonomi, dan sosial. Untuk itu diperlukan strategi kebijakan sehingga pertumbuhan jumlah penduduk lansia menjadi potensi yang turut membangun bangsa dan justru menjadi aset sumber daya manusia yang potensial(Maylasari et al., 2019).

Terapi komplementer untuk hipertensi adalah terapi musik dan terapi musik merupakan salah satu intervensi bagi perawat(Bulechek, Butcher, Dochterman, \& Wagner, 2013; Snyder \& Lindquist, 2010; Supriadi, Hutabarat, \& Monica, 2015). Musik langgam jawa merupakan salah satu musik asli dari Indonesia yang tumbuh dan berkembang baik di Indonesia serta mendapatkan tempat di masyarakat(Rachman \& Utomo, 2019). Alunan musik langgam jawa dapat menjadi media penting dalam proses penyembuhan karena menimbulkan perasaan yang menyenangkan(Castika \& Melati, 2019).

Berdasarkan hasil studi pendahuluan pada tanggal 29 April 2020 sampai tanggal 2 Juni 2020, 60 lansia yang dilakukan pemeriksaan di Desa Muara Rengas 30\% lansia bertekanan darah normal, 13,33\% lansia pra hipertensi, dan 56,66\% lansia mengalami hipertensi.

\section{METODE}

Desain penelitian ini menggunakan quasi experiment pre and post test without control. Dengan teknik consecutive sampling. Responden pada penelitian ini adalah lansia di Desa Muara Rengas sebanyak 30 lansia yang memenuhi kriteria inklusi 
yaitu lansia yang mengalami hipertensi primer, lansia yang menyukai musik langgam jawa, dan bersedia mengikuti penelitian. Kriteria eksklusi yaitu lansia yang mengalami gangguan pendengaran, lansia yang tirah baring, lansia yang mengkonsumsi obat antihipertensi, lansia berusia lebih dari 75 tahun. Lansia yang bersedia dan memenuhi kriteria diberikan surat informed consent sebagai responden.
Responden dibagi menjadi 2 kelompok yaitu kelompok terapi musik 15 menit dan terapi musik 30 menit.

Pada analisa data menggunakan uji Wilcoxon dan T-Test Paired untuk uji pre-intervensi dan post-intervensi sedangkan untuk uji post-intervensi antara keompok 15 menit dan 30 menit menggunakan uji mann whitney dan T-Test Independent.

\section{HASIL PENELITIAN}

Tabel 1 Distribusi Frekuensi Responden Berdasarkan Jenis Kelamin Dan Merokok Pada Lansia Hipertensi Di Desa Muara Rengas Pada Juni 2020

Frekuensi (n)

Persentase (\%)

\begin{tabular}{lcc}
\hline Jenis Kelamin & & \\
\hline Perempuan & 21 & 70 \\
Laki- laki & 9 & 30 \\
\hline Merokok & & \\
\hline Ya & 3 & 10 \\
Tidak & 27 & 90 \\
\hline
\end{tabular}

Tabel 2 Nilai Tedency Central Dari Usia, Dan Tekanan Darah

\begin{tabular}{|c|c|c|c|c|c|c|c|}
\hline \multirow{2}{*}{ Variabel } & \multirow{2}{*}{ Min } & \multirow{2}{*}{$\operatorname{Max}$} & \multirow{2}{*}{ Mean } & \multirow{2}{*}{ Median } & \multirow{2}{*}{$\begin{array}{c}\text { Std. } \\
\text { Deviasi }\end{array}$} & \multicolumn{2}{|c|}{ Normalitas Data } \\
\hline & & & & & & 15 Menit & 30 Menit \\
\hline Usia & 65 & 75 & 67,20 & 66,00 & 2,882 & $0,000^{1}$ & $0,002^{1}$ \\
\hline \multicolumn{8}{|l|}{$\begin{array}{l}\text { Tekanan } \\
\text { Sistol }\end{array}$} \\
\hline Sebelum & 140 & 201 & 155,90 & 151,50 & 15,041 & $0,151^{2}$ & $0,038^{1}$ \\
\hline Sesudah & 118 & 174 & 143,87 & 145,50 & 14,424 & $0,928^{2}$ & $0,189^{2}$ \\
\hline \multicolumn{8}{|l|}{$\begin{array}{l}\text { Tekanan } \\
\text { Diastol }\end{array}$} \\
\hline Sebelum & 90 & 134 & 97,87 & 94,00 & 9,930 & $0,002^{1}$ & $0,000^{1}$ \\
\hline Sesudah & 77 & 119 & 92,67 & 92,00 & 8,934 & $0,746^{2}$ & $0,574^{2}$ \\
\hline \multicolumn{8}{|l|}{ Nadi } \\
\hline Sebelum & 67 & 110 & 84,97 & 85,50 & 12,102 & $0,539^{2}$ & $0,479^{2}$ \\
\hline Sesudah & 65 & 100 & 82,23 & 81,00 & 9,402 & $0,154^{2}$ & $0,239^{2}$ \\
\hline
\end{tabular}

Keterangan : ${ }^{1}$ data berdistribusi tidak normal ${ }^{2}$ data berdistribusi normal 
Pada tabel 1 menunjukkan $70 \%$ dari responden mayoritas berjenis kelamin perempuan. Kebiasaan merokok lansia $10 \%$.

Berdasarkan Tabel 2 usia rata - rata responden adalah 67,20 (lansia muda) dengan SD 2,882. Rata - rata tekanan sistol sebelum dilakukan intervensi adalah 155,90 $\mathrm{mmHg}$ dengan SD 15,041 dengan tekanan sistol paling tinggi $201 \mathrm{mmHg}$. Setelah diberikan intervensi rata - rata tekanan sistol adalah 143,87 $\mathrm{mmHg}$ dengan SD 14,424 dan tekanan sistol paling rendah $118 \mathrm{mmHg}$. Sedangkan untuk rata - rata tekanan diastol sebelum diberikan intervensi adalah 97,87
mmHg dengan SD 9,930 tekanan diastol paling tinggi adalah 134 mmHg. Setelah diberikan intervensi rata - rata tekanan diastol adalah 92,67 $\mathrm{mmHg}$ dengan SD 8,934 tekanan diastol paling rendah 77 $\mathrm{mmHg}$.

Nadi rata- rata reponden sebelum diberikan intervensi adalah 84,97 dengan SD 12,102 untuk nadi tertinggi 110 setelah diberikan intervensi rata - rata nadi responden 82,23 dengan SD 9,492 untuk nadi terendah yaitu 65 .

Tabel 3 Perbedaan Tekanan Darah Sistol dan Diastol Pre-Intervensi Dan PostIntervensi 15 Menit $(n=15)$ dan 30 Menit $(n=15)$ pada Lansia Hipertensi di Desa Muara Rengas pada Bulan Juni 2020

\begin{tabular}{lllll}
\hline Kelompok & Mean \pm SD $($ Pre $)$ & $\begin{array}{l}\text { Mean } \pm \text { SD } \\
\text { (Post) }\end{array}$ & $\begin{array}{l}\text { Selisih } \\
\text { Mean }\end{array}$ & $\begin{array}{l}\text { Uji } \\
\text { Hipotesis }\end{array}$ \\
\hline Intervensi 15 Menit & & & & \\
Sistol & $152,53 \pm 11,115$ & $141,20 \pm 11,977$ & 11,33 & $0,000^{1}$ \\
Diastol & $96,40 \pm 6,947$ & $91,73 \pm 5,418$ & 4,67 & $0,013^{2}$ \\
\hline Intervensi 30 Menit & & & & \\
Sistol & $159,27 \pm 17,910$ & $146,53 \pm 16,501$ & 12,74 & $0,008^{2}$ \\
Diastol & $99,33 \pm 12,304$ & $93,60 \pm 11,581$ & 5,73 & $0,029^{2}$ \\
\hline Uji Hipotesis & & & & \\
Sistol & $0,367^{3}$ & $0,320^{4}$ & & \\
Diastol & $0,653^{3}$ & $0,576^{4}$ & & \\
\hline Ketangi
\end{tabular}

Keterangan : ${ }^{1}$ uji T-Test Paired ${ }^{2}$ Uji Wilcoxon ${ }^{3}$ Uji Mann Whitney ${ }^{4}$ Uji T-Test Independent

Berdasarkan tabel 3 rata - rata tekanan sistol kelompok 15 menit adalah $152,53 \mathrm{mmHg}$ dengan $\mathrm{SD}$ 11,115 dan rata - rata tekanan diastolnya $96,40 \mathrm{mmHg}$ dengan SD 6,947 setelah diberikan intervensi rata - rata tekanan sistol kelompok 15 menit adalah 141,20 dengan SD 11,977 dan rata - rata tekanan diastolnya 91,73 mmhg dengan SD 5,418. Dari data sistol dan diastol sebelum dan sesudah intervensi SD lebih kecil dibandingkan nilai rata rata nya yang mana artinya untuk data 
sistol dan diastol sebelum dan sesudah diberikan intervensi kurang bervariasi. Setelah dilakukan uji statistik diketahui nilai $\mathrm{p}$ value tekanan sistol adalah $0,000(<0,05)$ dan nilai $\mathrm{p}$ value tekanan diastol adalah $0,013 \quad(<0,05)$ maka secara statistik terdapat perbedaan tekanan sistol dan diastol pre- intervensi dan Post-Intervensi pada kelompok 15 menit.

Pada tabel 3 rata - rata tekanan sistol kelompok 30 menit adalah 159,27 mmHg dengan SD 17,910 dan ratarata tekanan diastolnya $99,33 \mathrm{mmHg}$ dengan SD 12,304 setelah diberikan intervensi rata - rata tekanan sistol kelompok 30 menit adalah 146,53 dengan SD 16,501 dan rata - rata tekanan diastolnya 93,60 $\mathrm{mmhg}$ dengan SD 11,581. Dari data sistol dan diastol sebelum dan sesudah intervensi SD lebih kecil dibandingkan nilai rata - rata nya yang mana artinya untuk data sistol dan diastol sebelum dan sesudah diberikan intervensi kurang bervariasi. Setelah dilakukan uji statistik diketahui nilai $\mathrm{p}$ value tekanan sistol adalah 0,008 $(<0,05)$

\section{PEMBAHASAN}

Berdasarkan tabel 1 dari 30 responden $70 \%$ responden berjenis kelamin perempuan. Hal ini dikarenakan data yang didapat berdasarkan pengukuran saat penelitian lebih banyak lansia perempuan yang mengalami hipertensi daripada lansia laki-laki. Jenis kelamin berkaitan dengan terjadinya hipertensi dimana pada masa paruh baya penyakit hipertensi lebih banyak terjadi pada wanita (Kusumawaty, Hidayat, \& Ginanjar, 2016). Saat wanita mulai memasuki usia lanjut mereka mengalami dan nilai $\mathrm{p}$ value tekanan diastol adalah 0,029 $(<0,05)$ maka secara statistik terdapat perbedaan tekanan sistol dan diastol pre- intervensi dan Post-Intervensi pada kelompok 30 menit.

Pada tabel 3 diketahui hasil analisis pre-intervensi tekanan sistol pada kelompok 15 menit dan 30 menit adalah 0,367 $(>0,05)$ dan tekanan diastol 0,653 $(>0,05)$, maka secara statistik tidak ada perbedaan tekanan sistol dan diastol pre-intervensi pada kelompok 15 menit dan 30 menit. Untuk hasil analisis post-intervensi tekanan sistol pada kelompok 15 menit dan 30 menit adalah 0,320 $(>0,05)$ dan tekanan diastol 0,576 $(>0,05)$, maka secara statistik tidak ada perbedaan efektivitas tekanan sistol dan diastol pre-intervensi pada kelompok 15 menit dan 30 menit.

Pada tabel 3 selisih rata - rata untuk kelompok 15 menit pada data sistol adalah 11,33 sedangkan pada data diastol 4,67. Untuk selisih rata - rata pada kelompok 30 menit data sistol 12,74 dan data diastol 5,73.

menopause, dimana menopause berhubungan dengan peningkatan tekanan darah karena adanya penurunan hormon estrogen, yang selama ini melindungi pembuluh darah dari kerusakan (Eiff, Plotz, Beck, \& Czernik, 1971; LeMone et al., 2018; Raharjo, Indrayanto, \& Riyadi, 2013).

Berdasarkan tabel 2 usia rata - rata usia responden berusia 67,20 (lansia muda) dengan nilai median 66,00 (lansia muda) . Usia sangat berkaitan dengan kejadian hipertensi dimana usia merupakan faktor risiko hipertensi yang tidak bisa diubah, saat 
seseorang berusia lanjut baroreseptor yang berfungsi mengatur tekanan darah,kelenturan arteri, resistensi perifer, mengalami penurunan sehingga tubuh kurang efektif dalam mengendalikan tekanan darah (Arif \& Hartinah, 2013; LeMone et al., 2018; Miller, 2012; Syahrini, Susanto, \& Udiyono, 2012).

Nadi rata - rata reponden sebelum diberikan intervensi adalah 84,97 setelah diberikan intervensi musik langgam jawa rata - rata nadi responden menjadi 82,23 hal ini dikarenakan pada saat mendengarkan alunan musik langgam jawa dengan irama yang lambat dan tempo yang stabil akan mempengaruhi detak nadi dimana detak nadi akan melambat mengikuti musik (Campbell, 2001; Castika \& Melati, 2019; Snyder \& Lindquist, 2010).

Rata - rata tekanan sistol sebelum diberikan intervensi adalah 155,90 $\mathrm{mmHg}$ (hipertensi I). Sedangkan pada rata - rata tekanan diastol sebelum diberikan intervensi adalah 97,87 $\mathrm{mmHg}$ (hipertensi I). Rata - rata tekanan sistol sesudah diberikan intervensi adalah 143,87 $\mathrm{mmHg}$ (hipertensi I). Sedangkan pada rata rata tekanan diastol sesudah diberikan intervensi adalah 92,67 $\mathrm{mmHg}$ (hipertensi I) (Bell et al., 2015).

Pada tabel 3 Menunjukkan ada perbedaan tekanan darah sistol dan diastol setelah diberikan terapi musik langgam jawa 15 menit selama 3 hari dengan rata - rata tekanan sistol sebelum 152,53 (hipertensi I) SD 11,115 setelah diberikan intervensi rata - rata tekanan sistol 141,20 mmHg (hipertensi I) dan SD 11,977 dengan $\mathrm{p}$ value $0,000 \quad(<0,05)$. Adapun rata - rata tekanan diastol sebelum diberikan intervensi rata rata tekanan darah menjadi 91,73 (hipertensi I) dan SD 5,418 dengan $\mathrm{p}$ value $0,013 \quad(<0,05)$. Setelah diberikan intervensi terapi musik langgam jawa 30 menit selama 3 hari ada perbedaan tekanan darah sistol dan diastol dengan rata - rata tekanan sistol sebelum 159,27 (hipertensi I) SD 17,910 setelah diberikan intervensi rata - rata tekanan sistol 146,53 $\mathrm{mmHg}$ (hipertensi I) dan SD 16,501 dengan $\mathrm{p}$ value $0,008(<0,05)$. Adapun rata - rata tekanan diastol sebelum diberikan intervensi 99,33 (hipertensi I) dan SD 12,304 setelah diberikan intervensi rata - rata tekanan darah menjadi 93,60 (hipertensi I) dan SD 11,581 dengan $\mathrm{p}$ value $0,029(<0,05)$. Pada tabel 4.3 Hasil penelitian ini menunjukkan tidak ada perbedaan efektivitas tekanan darah setelah dilakukan terapi musik langgam jawa selama 15 menit dan 30 menit selama 3 hari dengan $\mathrm{p}$ value sistol $0,320(>0,05)$ dan diastol 0,576 $(>0,05)$ sehingga $\mathrm{Ha}$ di tolak.

Dari hasil uji statistik yang telah dilakukan pemberian terapi musik langgam jawa selama 15 menit selama 3 hari dapat mempengaruhi tekanan darah dimana hal ini sesuai dengan penelitian Hidayah, Damanik, \& Elita (2015) yaitu tentang perbandingan efektivitas terapi musik klasik aromaterapi mawar terhadap tekanan darah pada pasien penderita hipertensi. Pemberian terapi musik langgam jawa selama 30 menit juga mempengaruhi tekanan darah dimana ini sesuai dengan penelitian Isnaini, (2012) yaitu tentang pengaruh musik langgam jawa keroncong terhadap perubahan tekanan darah pada lansia dengan hipertensi. Dari hasil uji statistik yang telah dilakukan 
pemberian terapi musik langgam jawa selama 3 hari dapat mempengaruhi tekanan darah dimana ini sesuai dengan penelitian Purnomo, Zulkipli, \& Pulungan (2018) yaitu tentang kombinasi terapi musik instrumental dan self hypnosis efektif untuk menurunkan tekanan darah klien hipertensi pada lansia hipertensi. Irama yang lambat dan tempo yang stabil pada alunan musik langgam jawa akan mempengaruhi detak jantung dimana detak jantung akan melambat mengikuti musik, detak jantung yang lebih lambat akan membuat tingkat stres serta ketegangan fisik lebih rendah, menenangkan fikiran dan membantu tubuh menyebuhkan diri (Campbell, 2001; Castika \& Melati, 2019; Snyder \& Lindquist, 2010). Selain itu, Adanya pelepasan pelepasan hormon endorfin yang membuat perasaan menyenangkan, pelepasan dopamine, peningkatan kadar kalsium serum pada saat seseorang mendengarkan musik menyebabkan vasodilatasi pada pembuluh darah sehingga tekanan darah menjadi turun (Chanda \& Levitin, 2013; LeMone et al., 2018; Sutoo \& Akiyama, 2004).

Setelah dilakukan uji statistik didapatkan hasil bahwa tidak ada perbedaan efektivitas tekanan darah setelah diberikan terapi musik langgam jawa selama 15 menit dan 30 menit . mendengarkan musik secara signifikan dapat meningkatkan kadar kalsium serum dan dopamin neostriatal sehingga menyebabkan vasodilatasi pada pembuluh darah menyebabkan adanya penurunan tekanan darah sehingga walaupun tidak ada perbedaan secara statistik jika dilihat pada tabel 3 terdapat perbedaan selisih dari rata - rata tekanan sistol dan diastol pada kedua kelompok (Salimpoor, Benovoy, Larcher, Dagher, \& Zatorre, 2011; Sutoo \& Akiyama, 2004).

\section{KESIMPULAN}

1. Ada pengaruh terapi musik langgam jawa selama 15 menit terhadap tekanan darah sistol pada lansia hipertensi

2. Ada pengaruh terapi musik langgam jawa selama 15 menit terhadap tekanan darah diastol pada lansia hipertensi

3. Ada pengaruh terapi musik langgam jawa selama 30 menit terhadap tekanan darah sistol pada lansia hipertensi

4. Ada pengaruh terapi musik langgam jawa selama 30 menit terhadap tekanan darah diastol pada lansia hipertensi

5. Tidak ada perbedaan efektivitas durasi waktu pemberian terapi musik langgam jawa terhadap tekanan darah pada lansia hipertensi

\section{SARAN}

Saran untuk masyarakat Desa Muara Rengas, diharapkan hasil penelitian ini bisa manambah wawasan masyarakat dalam mengendalikan tekanan darahnya dengan cara mendengarkan terapi musik langgam jawa di tambah dengan mengubah gaya hidup menjadi lebih sehat dengan mengkonsumsi makanan bergizi serta mengurangi konsumsi natrium, manajemen stres dan cukup istirahat agar hipertensi tidak bertambah parah. serta diharapkan dengan ini lansia rutin memeriksakan kesehatannya setiap bulan saat posyandu lansia di pustu desa muara rengas. 
Saran untuk petugas Kesehatan Desa Muara Rengas. Diharapkan hasil penelitian ini dapat menjadi referensi tambahan bagi petugas kesehatan di desa muara rengas dalam membantu masyarakat untuk menangani hipertensi dan diharapkan petugas kesehatan di desa muara rengas dapat membuat program untuk mengedukasi masyarakat dalam mencegah dan mengendalikan hipertensi berupa bagaimana cara memanajemen stres, mengedukasi makanan apa yang sebaiknya dihindari oleh penderita hipertensi, dan mengubah pola hidup yang lebih sehat.

Saran untuk institusi pendidikan. Diharapkan hasil dari penelitian ini dapat menambah referensi dalam proses pembelajaran di bidang ilmu keperawatan komplementer dan alternatif yang bisa digunakan saat melaksanakan praktik di rumah sakit maupun pengabdian kepada masyarakat.

Saran untuk peneliti selanjutnya, diharapkan bagi peneliti yang ingin melanjutkan penelitian ini bisa meneliti terkait variabel durasi waktunya, pada durasi waktu yang keberapakah tidak ada penurunan tekanan darah setelah diberikan terapi musik.

\section{DAFTAR PUSTAKA}

Arif, D., \& Hartinah, D. (2013). Factors Relating to The Incident of Hypertension in Elderly in Klumpit Village Mobile Community Health Center of Gribig Community Health Center , District Kudus. JIKK, 4(2), 18-34.
Bell, K., Twiggs, J., \& Olin, B. R. (2015). Hypertension: The Silent Killer : Updated JNC-8 Guideline Recommendations. Auburn: Continuing Education.

Bulechek, G. M., Butcher, H. K., Dochterman, J. M., \& Wagner, C. M. (2013). Nursing Interventions Classification (NIC) (Sixth). United Kingdom: Elsevier.

Campbell, D. (2001). Efek Mozart : Memanfaatkan Kekuatan Musik untuk Mempertajam Pikiran, Meningkatkan Kreativitas, dan Menyehatkan Tubuh. Jakarta: Gramedia Pustaka Utama.

Castika, Y., \& Melati, N. (2019). Efektivitas Terapi Musik Langgam Jawa dan Musik Alam Terhadap Perubahan Kadar Gula Dalam Darah Pada Orang dengan Diabetes Mellitus Tipe II Prambanan Klaten Tahun 2019. 7(1), 27-36.

Chanda, M. L., \& Levitin, D. J. (2013). The neurochemistry of music. Trends in Cognitive Sciences, 17(4), 179-193. https://doi.org/10.1016/j.tics.20 13.02.007

Eiff, A. W., Plotz, E. J., Beck, K. J., \& Czernik, A. (1971). The Effect of Estrogens and Progestins on Blood Pressure Regulation of Normotensive Women. Amerika Journal of Obstetrics and Gynecology, 109(6), 887-892. https://doi.org/https://doi.org/10 .1016/0002-9378(71)90802-7

Hidayah, N., Damanik, S. R. H., \& Elita, V. (2015). Perbandingan Efektivitas Terapi Musik Klasik 
Dengan Aromaterapi Mawar Terhadap Tekanan Darah Pada Penderita Hipertensi. Jurnal Online Mahasiswa Program Studi Ilmu Keperawatan Universitas Riau, 2(2), 13171326.

Isnaini, S. (2012). Pengaruh Musik Langgam Jawa Keroncong Terhadap Perubahan Tekanan Darah Pada Lansia Dengan Hipertensi Di Shelter Gondang 2 Wukirsari Cangkringan Sleman Yogyakarta (Universitas Muhammadiyah Yogyakarta). Retrieved from http://repository.umy.ac.id/hand le/123456789/5748

Kementerian Kesehatan Republik Indonesia. (2017). Analisis Lansia di Indonesia. Pusat Data Dan Informasi Kementerian Kesehatan RI, 1-6. Retrieved from

www.depkes.go.id/download.ph p?file $=$ download/.../infodatin lansia 2016.pdf\%0A

Kusumawaty, J., Hidayat, N., \& Ginanjar, E. (2016). Hubungan Jenis Kelamin dengan Intensitas Hipertensi pada Lansia di Wilayah Factors Related Events Sex with Hypertension in Elderly Work Area Health District Lakbok Ciamis. 16(2), 46-51.

LeMone, P., M.Burke, K., \& Bauldoff, G. (2018). Buku Ajar Keperawatan Medikal Bedah Gangguan Kardiovaskuler. Jakarta: EGC.

Maylasari, I., Rachmawati, Y., Wilson, H., Nugroho, S. W., Sulistyowati, N. P., \& Dewi, F. W. R. (2019). Statistik
Penduduk Lanjut Usia. Jakarta.

Miller, C. A. (2012). Nursing for Wellness in Older Alduts (6th ed.). China: Library of Congress Catalogin.

Purnomo, E., Zulkipli, \& Pulungan, Z. S. A. (2018). Kombinasi Terapi Musik Instrumental Dan Self Hypnosis. Journal Of Health, Education and Literacy, 1(1), 17-23.

Rachman, A., \& Utomo, U. (2019). The Rhythm Pattern Adaptation of Langgam Jawa in Kroncong. 2nd International Conference on Arts and Culture (ICONARC 2018), 276(Iconarc 2018), 99101.

https://doi.org/10.2991/iconarc18.2019 .78

Raharjo, D., Indrayanto, Y., \& Riyadi, S. (2013). Hubungan antara Menopause dengan Hipertensi di Puskesmas Penumping Surakarta. Nexus Kedokteran Komunitas, 2(3).

Salimpoor, V. N., Benovoy, M., Larcher, K., Dagher, A., \& Zatorre, R. J. (2011).

Anatomically Distinct Dopamine Release During Anticipation and Experience of Peak Emotion to Music. Nature Neuroscience, 14(2), 257-262.

Smeltzer, S. C., \& Bare, B. G. (2017). Keperawatan Medikal Bedah (12th ed.). Jakarta: EGC.

Snyder, M., \& Lindquist, R. (2010). Complementary and Alternative Therapies in Nursing. In Current and Emerging Treatments for Psoriasis (sixth). https://doi.org/10.2217/EBO.11. 
162

Supriadi, D., Hutabarat, E., \& Monica, V. (2015). Pengaruh Terapi Musik Tradisional Kecapi Suling Sunda Terhadap Tekanan Darah Pada Lansia Dengan Hipertensi. Skolastik Keperawatan, 1(2), 29-35.

Sutoo, D., \& Akiyama, K. (2004). Music Improves Dopaminergic Neurotransmission :

Demonstration Based on the
Effect of Music on Blood

Pressure Regulation. Brain

Research, 1016(2), 255-262.

Syahrini, E. N., Susanto, H. S., \& Udiyono, A. (2012). Faktor Faktor Risiko Hipertensi Primer di Puskesmas Tlogosari Kulon Kota Semarang. Jurnal

Kesehatan Masyarakat, 1(2), 315-325. 